\title{
Feasibility analysis of an innovative naval on- board power-train system with hydrogen- based PEMFC technology
}

\author{
Simona Di Micco ${ }^{1, *}$, Mariagiovanna Minutillo ${ }^{2,3}$, Antonio Forcina ${ }^{1}$, Viviana \\ Cigolotti ${ }^{3,4}$, Alessandra Perna $^{5}$ \\ ${ }^{1}$ Univerisity of Naples "Parthenope", Naples, Italy \\ ${ }^{2}$ Department of Industrial Engineering, University of Salerno, Salerno, Italy \\ ${ }^{3}$ ATENA Future Technology, Naples, Italy \\ ${ }^{4}$ ENEA - Italian National Agency for New Technologies, Energy and Sustainable Economic \\ Development, Naples, Italy \\ ${ }^{5}$ University Cassino and Southern Lazio, Cassino, Italy
}

\begin{abstract}
The maritime transportation sector is one of the main contributors to global emissions of greenhouse gases (GHGs), volatile organic compounds (VOCs), particulate matter (PM), hazardous air pollutants, NOX and SOX. In particular, it is estimated that the $\mathrm{CO} 2$ emissions in this sector are about 1 Gt every year.

The International Maritime Organization (IMO) adopted stringent emission limits in its Tier III regulation, most notably on NOX and SOX emissions and pledged to reach a reduction in greenhouse gas (GHG) emissions from international shipments by at least $50 \%$ by the year 2050 , compared to 2008 emissions. For emission control areas (ECAs) these requirements are particularly strict and will be difficult to meet with traditional diesel engines and bunker fuels. Therefore, ship owners need to adopt solutions to bring emissions within these and other future limits by means of environmentally friendly fuels and high efficiency propulsion technologies. In this context, hydrogen and fuel cells play a crucial role, thanks to their low criteria pollutant and GHG emission.

This paper presents a techno-economic feasibility study for replacing the conventional diesel engine powertrain, usually employed in Ro-Pax ferries, with an innovative system based on polymer electrolyte membrane fuel cell (PEMFC) technology. The ferry is actually powered by four diesel engines, which deliver a total output of $37.8 \mathrm{MW}$. The ferry also has two auxiliary engines which give an output of $4.0 \mathrm{MW}$ and also two $2.0 \mathrm{MW}$ bow thrusters for its manoeuvring. The energy analysis has allowed to define the hydrogen consumption for each cruise, as well as the optimal size of the innovative propulsion system. In particular, The PEMFC powertrain is sized at the same maximum power output as the main diesel engine and, thanks to the modular architecture of fuel cells and their flexible performance at partial load, the auxiliary engines are not contemplated. Moreover, in order to identify the best solution in terms of ship's weight and space requirements, two hydrogen storage solutions based on compressed hydrogen technology and
\end{abstract}

*Corresponding author: simona.dimicco@studenti.uniparthenope.it 
liquefied hydrogen technology, have been analyzed and compared. The economic assessment has been carried out by estimating the CAPEX and OPEX for each $\mathrm{H} 2$ storage technology by considering short-term, mid-term and long-term scenarios (from 2020 to 2050).

\section{Introduction}

Although maritime transport is typically viewed as an environmentally friendly transport mode, it is one of the largest greenhouse gas (GHG) emitting sectors of the global economy, responsible for around $1 \mathrm{Gt}$ of $\mathrm{CO} 2 \mathrm{eq}$ every year $[1,2]$. As matter of fact, the global emissions from the maritime sector is responsible for $10-15 \%$ of anthropogenic sulfur (SOx) and nitrogen oxide (NOx) emissions, as well as approximately $3 \%$ of the carbon dioxide (CO2) emissions [3]. The International Maritime Organization (IMO) has set ambitious goals to reduce, and eventually eliminate, greenhouse gas (GHG) emissions from international shipping [4]. The decarbonization of maritime sector will require changes in on-board energy storage and in energy conversion systems. Therefore, a range of technical and operational measures based on the introduction of carbon-free fuels, both on ships and in ports, can contribute to reducing emissions [5-8].

New renewable fuels and new energy conversion technologies, like the fuel cells can pave the way for the decarbonization in the maritime sector [9-12].

In Europe the interest in the maritime sector decarbonization is high. FCs and $\mathrm{H} 2$ have been demonstrated in e.g. submarines, small in-land and near coastal vessels, proving the viability of the technology. In addition, demonstration projects on small ferries are under construction. Larger vessels are generally at the design study stage and a range of fuels and fuel cell types are currently being tested.

Demonstration projects (i.e. MARANDA, FLAGSHIPS, ShipFC, H2PORTS) are underway to highlight the viability of $\mathrm{H} 2$ to power ships using FCs and modified combustion engines and several studies are available in the current technical literature.

Dall'Armi et al., propose a process simulation study to analyze the peak shaving services that a hybrid PEMFC/Li-ion battery propulsion system can provide to a small RoRo vessel and a passenger ferry. They also evaluated different compressed hydrogen storage solutions depending on the cruise duration [13].

Rivarolo et al., present the development of a PEMFC-based system for a 200 people ferry using a time-dependent thermo-economic analysis to determine the optimal operating conditions for the fuel cell that minimize operating costs [14].

Choi et al [15] developed a PEMFC-battery hybrid propulsion system for a tourist boat, and demonstrated the reliable operation in the coastal waters of South Korea.

Jeong et al [16] analyzed a hybrid propulsion system consisting of a LNG-fueled combustion engine and a hydrogen-fueled PEMFC.

Based on this background, it is possible to affirm that there is a great interest in developing hydrogen-based powertrain on-board ships, even if several issues, from technical and economic points of view, have to be furtherly and deeply analyzed.

In this work a techno-economic feasibility study for replacing the conventional diesel engine powertrain usually employed in ro-pax ferries (about $38 \mathrm{MW}$ ) with an innovative power system based on polymer electrolyte membrane fuel cell (PEMFC) technology, is presented. The hydrogen consumption for each cruise, as well as the optimal size of the innovative propulsion system is performed by means of the energy balance analysis. In particular, the PEMFC powertrain is sized at the same maximum power output of the main diesel engine and, thanks to the modular architecture of fuel cells and their flexible performance at partial load, the auxiliary engines are not contemplated. Moreover, in order to identify the best 
solution in terms of ship's weight and space requirements, two hydrogen storage solutions based on compressed hydrogen technology and liquefied hydrogen technology, are analyzed and compared.

The economic assessment is carried out by estimating the CAPEX and OPEX for each $\mathrm{H}_{2}$ storage technology by considering short-term, mid-term and long-term scenarios (from 2020 to 2050).

\section{Ro-Pax Description and Operation}

The case study refers to a Ro-Pax ferry, a large ship widely used for reaching the islands (Fig. 1). It is designed as two ships in one, both a passenger/vehicles ferry and a cargo transporter, with three large freight decks, loaded by a single stern door and a car deck, loaded via a side ramp.

The selected Ro-Pax is able to accommodate 1,360 passengers and 1,380 vehicles. It has a length overall (LOA) of $215.44 \mathrm{~m}$, a beam of $31.88 \mathrm{~m}$, a draught of $6.04 \mathrm{~m}$ and shows a carrying capacity of 59,925 Gross Tonnage. The Ro-Pax operates short-distance voyages, with a cruise duration of 12 hours, an average speed of 17.2 knots, travelling for $211.0 \mathrm{~nm}$ [17].

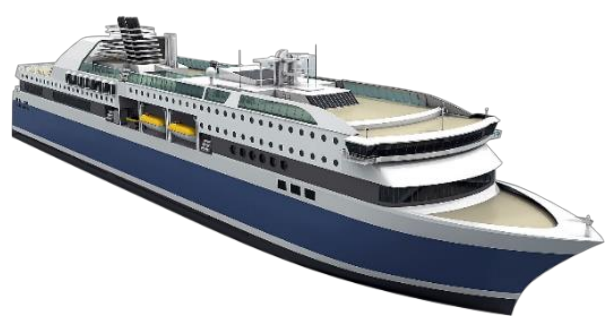

Fig. 1. Typical layout of Ro-Pax ferry [18].

The ferry is powered by four Wärtsilä 9L46C main diesel engines (MEs), which have a total power output of $37.8 \mathrm{MW}$, and two Wärtsilä 9L32 auxiliary engines (AEs), which give an output of $4 \mathrm{MW}$. It is equipped with two bow thrusters, two stabilizers and twin rudders [19]. In particular, the main engine is used for propulsion during navigation, where the load demand has an almost constant trend, while the auxiliary engine is used during docking and in-port operation and to meet the electricity needs on board during the cruise. Table 1 provides the detailed specifications of the Ro-Pax ferry.

Table 1. General characteristics of Ro-Pax ferry [17].

\begin{tabular}{|l|c|}
\hline \multicolumn{1}{|c|}{ IMO } & 9208629 \\
\hline \multicolumn{1}{|c|}{ Flag } & Bahamas [BS] \\
\hline Gross Tonnage(tons) & $59,925.0$ \\
\hline Length Overall (m) & 215.44 \\
\hline Engine Room Volume (m ${ }^{3}$ ) & $1,660.0$ \\
\hline Fuel Room Volume (m ${ }^{3}$ ) & $1,000.0$ \\
\hline Fuel Mass Capacity (ton) & $1,025.0$ \\
\hline MEs Mass Capacity (ton) & $116.5 \times 4$ \\
\hline AEs Mass Capacity (ton) & $54.2 \times 2$ \\
\hline
\end{tabular}


The load profile of the Ro-Pax ferry, that considers both the power needed for the main engine (ME) and the auxiliary engines (AEs), is depicted in Fig.2.

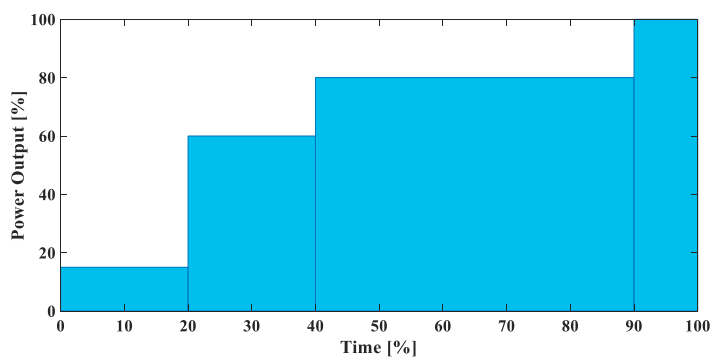

Fig. 2. Ro-Pax ferry load profile

\section{Power-Train System Based On PEMFC Technology}

The feasibility analysis for replacing the diesel-based power-train system with a PEMFCbased one has been assessed taking into account the size of components, the weight and space requirements.

For the proposed power-train system, a $100 \mathrm{~kW}$ PEMFC module (depicted in Fig. 3), developed by Ballard [20,21], has been selected. Table 2 summarized the PEMFC module's characteristics.

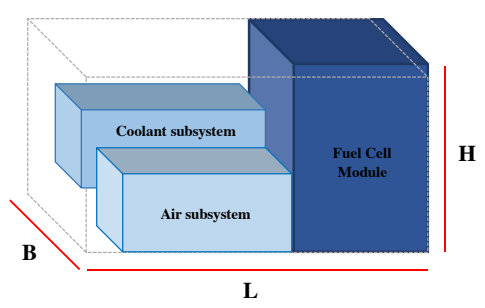

Fig.3. $100 \mathrm{~kW}$ PEMFC module design [20,21]

The PEMFC has been sized as the same nominal power capacity of the reference main diesel engine (i.e., $37.8 \mathrm{MW}$ ). Consequently, a PEMFC power-train system made up of $378 \times 100 \mathrm{~kW}$ units has been employed. Thanks to the modular configuration of this power unit (378 modules $\times 100 \mathrm{~kW}$ each), the auxiliary engines have been not contemplated, considering that the power requirements during docking and in-port operations can be satisfied thought the PEMFC power unit, with a great advantage on the size-reduction of the on-board power-train system.

Table 2. 100kW PEMFC module characteristics [20,21]

\begin{tabular}{|l|c|c|c|c|}
\hline & $\begin{array}{c}\text { Fuel Cell } \\
\text { Module }\end{array}$ & $\begin{array}{c}\text { Coolant } \\
\text { Subsystem }\end{array}$ & $\begin{array}{c}\text { Air } \\
\text { Subsystem }\end{array}$ & $\begin{array}{c}\text { PEMFC } \\
\text { (added margin 5 } \\
\text { mm each side) }\end{array}$ \\
\hline $\mathrm{L}(\mathrm{m})$ & 0.869 & 0.737 & 0.676 & 1.616 \\
\hline $\mathrm{B}(\mathrm{m})$ & 1.200 & 0.529 & 0.418 & 1.210 \\
\hline $\mathrm{H}(\mathrm{m})$ & 0.506 & 0.379 & 0.352 & 0.516 \\
\hline Mass $(\mathrm{kg})$ & 285.0 & 44.0 & 61.0 & 390 \\
\hline Power density $(\mathrm{kW} /$ ton$)$ & - & - & - & 256 \\
\hline Volumetric Power density $\left(\mathrm{kW} / \mathrm{m}^{3}\right)$ & - & - & - & 99 \\
\hline
\end{tabular}


For storing hydrogen on-board, two alternative hydrogen storage solutions have been taken into account:1) cryogenic tanks; 2) high pressure tanks. In particular, gaseous hydrogen has been considered both at 350 bar and 700 bar, at ambient temperature.

Table 3 summarizes the main characteristics of the selected storage technologies, whereas in Fig. 4 shows the schematic configuration of the PEMFC-based power-train system.

Table 3. Main characteristics of the considered storage systems

\begin{tabular}{|l|c|c|c|}
\hline & $\begin{array}{c}350 \text { bar } \\
\text { Compressed } \mathrm{H}_{2}\end{array}$ & $\begin{array}{c}700 \text { bar } \\
\text { Compressed } \mathrm{H}_{2}\end{array}$ & $\begin{array}{c}\text { Liquefied } \\
\mathrm{H}_{2}\end{array}$ \\
\hline \multicolumn{1}{|c|}{ Ref. } & {$[22]$} & {$[23]$} & {$[24]$} \\
\hline External Diameter $(\mathrm{mm})$ & 408.4 & 460.0 & 3,000 \\
\hline Length $(\mathrm{mm})$ & $2,100.0$ & $1,359.6$ & 18,000 \\
\hline Empty Weight $(\mathrm{kg})$ & 81.0 & 87.5 & 29,650 \\
\hline Internal Volume $\left(\mathrm{m}^{3}\right)$ & 0.20 & 0.13 & 76 \\
\hline
\end{tabular}
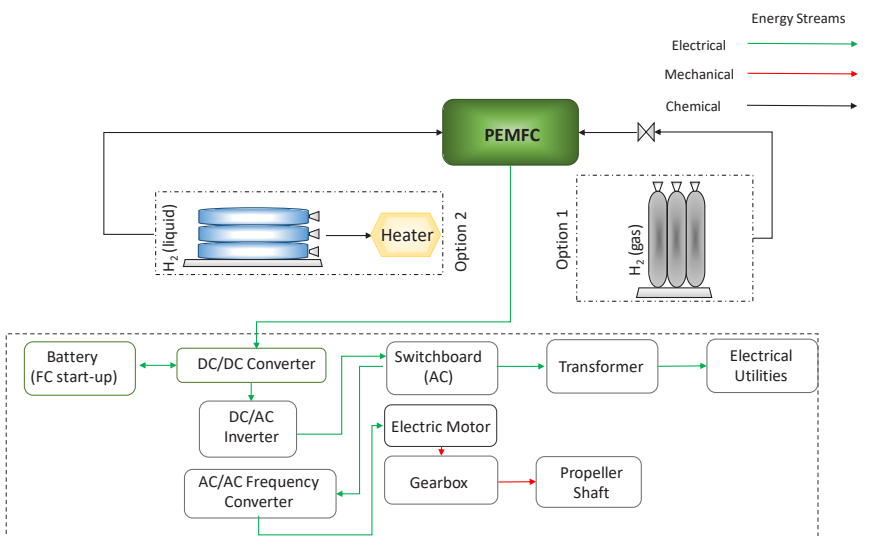

Fig. 4: Configuration of the on-board power-train system with hydrogen-based PEMFC

As shown in Fig. 4, a DC/DC converter is applied after the PEMFC for regulating the voltage provided by the PEMFC. Besides, a DC/AC inverter is needed, since the electric motor is supplied in $\mathrm{AC}$. It is connected to $\mathrm{AC} / \mathrm{AC}$ converter for regulating the voltage.

The AC switchboard allows to supply the electrical utilities, so that, according to the different type of load, a transformer is also considered.

The electric power needed for the electric motor is regulated with a frequency converter, which allows to operates for the so the entire range of speeds. The electric motor is connected to the propeller shaft by means of a gearbox.

The efficiencies of these components have not been considered in this analysis.

\section{Hydrogen Consumption Assessment}

The hydrogen consumption (HC) in each load condition (i) is calculated as reported in [25]:

$$
H C(i)=\frac{L_{f}(i) \cdot W_{P E M F C}}{L H V_{H_{2}} \cdot \eta(i)}
$$


where, $W_{P E M F C}$ is the nominal power of the PEMFC system, $L_{f}$ is the load factor of the RoPax ferry (Fig. 2), $L H V_{\mathrm{H}_{2}}$ represents the hydrogen lower heating value $(120 \mathrm{MJ} / \mathrm{kg})$, and $\eta$ is the PEMFC efficiency (calculated from the polarization curve provided by the manufacturer). Therefore, considering the fuel cell operation during the cruise (12 hours), the total hydrogen consumption (THC) has been calculated:

$$
T H C=\int_{0}^{t_{f}} \frac{L_{f}(i) \cdot W_{P E M F C}}{L H V_{H_{2}} \cdot \eta(i)} d t
$$

\section{Economic Assessment}

The economic assessment has been carried out comparing the PEMFC-based and dieselbased powertrain systems. In particular, the Capital Expenditure (CAPEX), as well as the Operational Expenditure (OPEX) for each $\mathrm{H}_{2}$ storage technology, have been estimated, considering different cost scenarios: current, near-term, mid-term, long-term and target scenario (ranging from 2020 to 2050).

Table 4 summarizes the assumed investment costs for the selected technologies, in each considered scenario.

Table 4. Investment costs for the plant components

\begin{tabular}{|l|c|c|c|c|c|c|}
\hline Investment costs & Unit & $\begin{array}{c}\text { Current } \\
\text { Scenario }\end{array}$ & $\begin{array}{c}\text { Near-term } \\
\text { Scenario }\end{array}$ & $\begin{array}{c}\text { Mid-term } \\
\text { Scenario }\end{array}$ & $\begin{array}{c}\text { Long-term } \\
\text { Scenario }\end{array}$ & $\begin{array}{c}\text { Target } \\
\text { Scenario }\end{array}$ \\
\hline PEMFC $[20,26,27]$ & $\$ / \mathrm{kW}$ & 960.0 & 350.0 & 170.0 & 130.0 & 92.4 \\
\hline Evaporator ${ }^{*}[28]$ & $\mathrm{k} \$$ & 200.0 & 190.0 & 180.0 & 160.0 & 145 \\
\hline $\mathrm{GH}_{2}$ storage $[29,30]$ & $\$ / \mathrm{kg}$ & 600.0 & 333.0 & 300.0 & 266.0 & 166.0 \\
\hline $\mathrm{LH}_{2}$ storage $[31-33]$ & $\$ / \mathrm{kg}$ & 165.0 & 165.0 & 150.0 & 110.0 & 70.0 \\
\hline
\end{tabular}

${ }^{*}$ Only needed for $\mathrm{LH}_{2}$

\section{Results and Discussion}

Considering a PEMFC average efficiency equal to $45 \%$, the overall hydrogen consumption during one cruise is calculated equal to 15.9 tons. By assuming a fuel margin percentage of $10 \%$ for safety conditions, the hydrogen to be stored on-board is 17.5 tons.

\subsection{Technical analysis}

In order to verify the feasibility replacement of the conventional diesel engine powertrain with the proposed one, the engine room and the fuel room characteristics (see table 1) have been taken into account. In particular, the weights and volumes of the powertrain systems have been calculated for ensuring the compatibility with the available space on the ferry. Considering the number of the PEMFC units (378) and the geometric parameters of each unit (see table 3), the new power unit allows to reduce the volume and weight of the engine room, with respect to the reference diesel-based solution of about $51.1 \%$ and $74.3 \%$ respectively, as reported in Table 5 (for the Diesel powertrain system data refers to both the MEs and AEs $[34,35])$. Therefore, both an additional volume, as well as a saved weight, is available for storing hydrogen. In particular, the overall available volume in the engine room is $879.1 \mathrm{~m}^{3}$ and the saved weight is 426.6 tons. 
Table 5. Powertrain systems: weights and volumes comparison

\begin{tabular}{|l|c|c|}
\hline Data & Diesel powertrain system $[34,35]$ & PEMFC powertrain system [20,21] \\
\hline Volume $\left(\mathrm{m}^{3}\right)$ & 780.9 & 381.8 \\
\hline Weight $($ tons $)$ & 574.3 & 147.7 \\
\hline
\end{tabular}

With referring to the calculation of volume and weight for the selected hydrogen storage solutions (gaseous, $\mathrm{GH}_{2}$, and liquid, $\mathrm{LH}_{2}$, hydrogen storage), the main hydrogen properties, in terms of Gravimetric Energy Density $(\mathrm{kWh} / \mathrm{kg})$ and Volumetric Energy Density $\left(\mathrm{kWh} / \mathrm{m}^{3}\right)$, have been taken into account (Table 6).

Table 6. Hydrogen fuel properties

\begin{tabular}{|c|c|c|c|c|}
\hline Fuel Property & Units & $\begin{array}{c}\mathrm{GH}_{2} \\
350 \mathrm{bar}\end{array}$ & $\begin{array}{c}\mathrm{GH}_{2} \\
700 \text { bar }\end{array}$ & $\mathrm{LH}_{2}$ \\
\hline $\begin{array}{l}\text { Hydrogen Low } \\
\text { Heating Value }\end{array}$ & $\begin{array}{c}\mathrm{MJ} / \mathrm{kg} \\
(\mathrm{kWh} / \mathrm{kg})\end{array}$ & $\begin{array}{l}120.0 \\
(33.3)\end{array}$ & $\begin{array}{l}120.0 \\
(33.3)\end{array}$ & $\begin{array}{l}120.0 \\
(33.3)\end{array}$ \\
\hline $\begin{array}{c}\text { Tank Gravimetric } \\
\text { Energy Density }\end{array}$ & $\begin{array}{c}\mathrm{MJ} / \mathrm{kg} \\
(\mathrm{kWh} / \mathrm{kg})\end{array}$ & $\begin{array}{c}6.3 \\
(1.7) \\
\end{array}$ & $\begin{array}{c}6.5 \\
(1.8) \\
\end{array}$ & $\begin{array}{l}17.3 \\
(4.8) \\
\end{array}$ \\
\hline $\begin{array}{l}\text { Tank Volumetric } \\
\text { Energy Density }\end{array}$ & $\begin{array}{c}\mathrm{MJ} / \mathrm{m}^{3} \\
\left(\mathrm{kWh} / \mathrm{m}^{3}\right)\end{array}$ & $\begin{array}{l}1963.6 \\
(545.5) \\
\end{array}$ & $\begin{array}{l}2666.7 \\
(740.7) \\
\end{array}$ & $\begin{array}{r}7859.6 \\
(2183.2)\end{array}$ \\
\hline
\end{tabular}

Table 7 summarizes and compares the results in terms of weight and the volume for each proposed storage technology with the diesel system.

Table 7. Fuel storage systems: weights and volumes comparison

\begin{tabular}{|l|c|c|c|c|}
\hline \multirow{2}{*}{ Data } & Diesel Storage system & \multicolumn{3}{|c|}{$\mathrm{H}_{2}$ Storage system } \\
\cline { 3 - 5 } & & 350 bar $\mathrm{GH}_{2}$ & 700 bar $\mathrm{GH}_{2}$ & $\mathrm{LH}_{2}$ \\
\hline Volume $\left(\mathrm{m}^{3}\right)$ & 78.3 & 971.3 & 666.3 & 436.3 \\
\hline Weight (tons) & 65.4 & 512.0 & 275.6 & 119.2 \\
\hline
\end{tabular}

By analyzing the data illustrated in table 7 , it is possible to underline that:

- the volume of the hydrogen storage systems is $12.4,8.5$ and 5.6 times higher (for 350 bar $\mathrm{GH}_{2}, 700$ bar $\mathrm{GH}_{2}, \mathrm{LH}_{2}$, respectively) compared to the diesel storage system;

- the weight is 7.8, 4.2 and 1.8 times higher (for 350 bar $\mathrm{GH}_{2}, 700$ bar $\mathrm{GH}_{2}, \mathrm{LH}_{2}$, respectively) compared to the diesel storage system.

Furthermore, all the hydrogen solutions are suitable in terms of weight and volume (see Table 1) even if the number voyages (without refueling) are drastically reduced. As matter of fact, considering that the vessel has a fuel room with a volume of $1000 \mathrm{~m}^{3}$, the number of voyages decreases from 12.8 (with the diesel), to $1.03,1.5$ and 2.3 considering the hydrogen storage systems ( 350 bar $\mathrm{GH}_{2}, 700$ bar $\mathrm{GH}_{2}, \mathrm{LH}_{2}$, respectively).

Figs. 5-6, compare the weights and volumes of the hydrogen-based power train system (fuel cells and hydrogen storage tanks) with those of the conventional diesel engine system (MEs, AEs and diesel tank). 


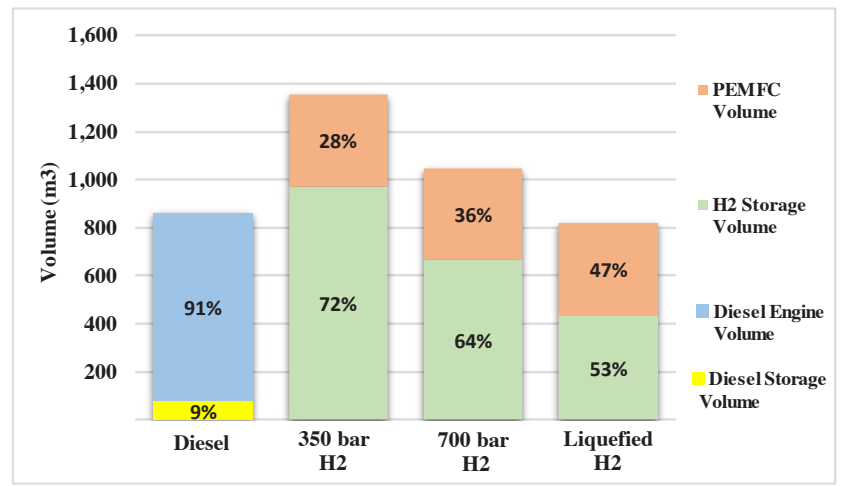

Fig.5: Total volume comparison for each case

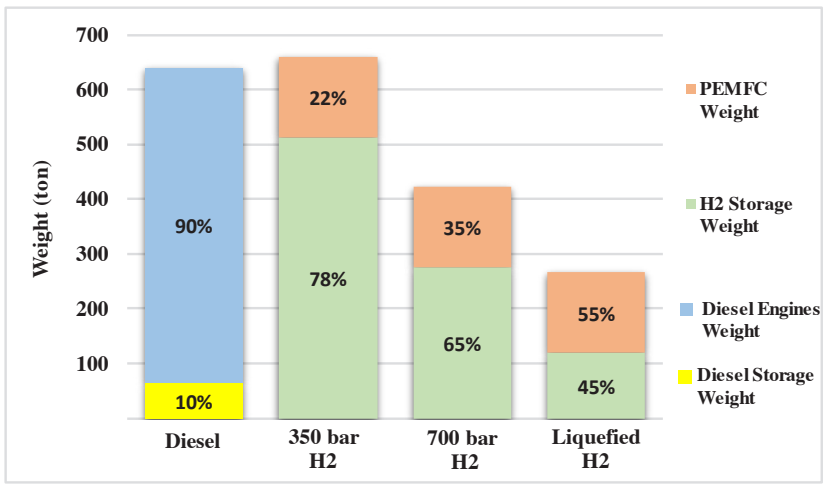

Fig 6: Total weight comparison for each case

It is worth noticing that on the Ro-Pax ferry the replacement of the diesel ICE with hydrogenbased power train causes an increase of the total occupied volume in all the analyzed hydrogen storage systems; on the other hand, the 700 bar $\mathrm{GH}_{2}$ and $\mathrm{LH}_{2}$ solutions involve a reduction in weight compared to the conventional solution.

\subsection{Economic Analysis}

The economic assessment is carried out by estimating the CAPEX and OPEX for each $\mathrm{H}_{2}$ storage technology, in all considered scenarios (from 2020 to 2050).

Table 8 summarizes the investment cost of the proposed PEMFC-based system in each considered scenario.

Table 8. CAPEX for the proposed power train systems

\begin{tabular}{|c|c|c|c|c|c|c|}
\hline $\begin{array}{c}\text { System } \\
\text { Configurations }\end{array}$ & Unit & $\begin{array}{c}\text { Current } \\
\text { Scenario }\end{array}$ & $\begin{array}{c}\text { Near-term } \\
\text { Scenario }\end{array}$ & $\begin{array}{c}\text { Mid-term } \\
\text { Scenario }\end{array}$ & $\begin{array}{c}\text { Long-term } \\
\text { Scenario }\end{array}$ & $\begin{array}{c}\text { Target } \\
\text { Scenario }\end{array}$ \\
\hline PEMFC\& $\mathrm{LH}_{2}$ storage & $\mathrm{k} \$$ & $39,818.0$ & $16,365.0$ & $9,226.0$ & $6,997.0$ & $4,861.0$ \\
PEMFC\& $\mathrm{GH}_{2}$ storage & $\mathrm{k} \$$ & $47,529.0$ & $19,100.0$ & $11,666.0$ & 9,560 & $6,392.0$ \\
\hline Diesel engine System* & $\mathrm{k} \$$ & $20,390.0$ & - & - & - & - \\
\hline
\end{tabular}

${ }^{*}$ The cost of diesel tanks is considered negligible

It is worth noticing how, in the current Scenario, considering an average specific capital cost of diesel engines equal to $478 \$ / \mathrm{kW}[21]$, the proposed system is not comparable with respect 
to the Diesel engine system. It becomes comparable and competitive in the other scenarios, because of forecasted cost reduction of PEMFC stack system [35].

For the OPEX, only the cost for the fuel consumption has been considered. In particular, the hydrogen consumption for one cruise (17.5 tons) and its average retail price (available for light duty and heavy-duty vehicles) on the market as a function of time have been taken into account.

Table 9 summarizes the Operational Expenditure (OPEX) of the proposed PEMFC-based system in each considered scenario.

Table 9. OPEX: $\mathrm{H}_{2}$ VS Diesel for the different scenarios (for 1 cruise)

\begin{tabular}{|c|c|c|c|c|c|c|}
\hline & Unit & $\begin{array}{c}\text { Current } \\
\text { Scenario }\end{array}$ & $\begin{array}{c}\text { Near-term } \\
\text { Scenario }\end{array}$ & $\begin{array}{c}\text { Mid-term } \\
\text { Scenario }\end{array}$ & $\begin{array}{c}\text { Long-term } \\
\text { Scenario }\end{array}$ & $\begin{array}{c}\text { Target } \\
\text { Scenario }\end{array}$ \\
\hline Fuel costs & & & & & & \\
\hline $\mathrm{H}_{2}$ average price [36] & $\$ \mathrm{~kg}$ & 16.5 & 13.0 & 10.0 & 7.0 & 4.0 \\
\hline Diesel average price [30] & $\$ \mathrm{~kg}$ & 0.5 & 0.8 & 1.0 & 1.1 & 1.3 \\
\hline OPEX & & & & & & \\
\hline $\mathrm{H}_{2}$ consumption cost & $\mathrm{k} \$$ & 288.8 & 227.5 & 175.0 & 122.5 & 70.0 \\
\hline Diesel consumption cost & $\mathrm{k} \$$ & 32.7 & 52.3 & 65.4 & 71.9 & 98.0 \\
\hline
\end{tabular}

Hydrogen price decreases from $\$ 16.5 / \mathrm{kg}$ to $\$ 4 / \mathrm{kg}$ over the time, while the diesel price increases from $\$ 0.5 / \mathrm{kg}$ to $\$ 1.3 / \mathrm{kg}[33,36]$.

It is worth noticing that that the fuel cell-based system is competitive from the operating cost perspective only at the target scenario (2050).

\section{Conclusion}

In this paper a techno-economic feasibility analysis, for integrating a polymer electrolyte membrane fuel cell (PEMFC) technology as a propulsion system on-bard ocean-going vessel, has been carried out. The ship selected in this study is a Ro-Pax ferry, a passenger/vehicles ferry and a cargo transporter, currently powered by four diesel engines, which have a total power output of $37.8 \mathrm{MW}$, and two auxiliary engines, which give an output of $4 \mathrm{MW}$.

The PEMFC system has been designed to completely replace the main diesel engine as well as the auxiliary engines with 378 units of $100 \mathrm{~kW}$ each.

Two different hydrogen storage technologies have been taken into account in this study: compressed gaseous hydrogen (at 350 bar or at 700 bar) and liquid hydrogen.

The results show that the PEMFC-based powertrain solution is characterized by $54.2 \%$ less space and $74.3 \%$ less weight compared to a diesel engine with the same power output, possibly allowing for additional space saving in the engine room.

As concerns the hydrogen storage technologies, it has been demonstrated that in terms of volume, the hydrogen storage systems are 12.4, 8.5 and 5.6 fold-higher for 350 bar GH$_{2}, 700$ bar $\mathrm{GH}_{2}, \mathrm{LH}_{2}$ compared to diesel storage system while 7.8, 4.2 and 1.8 fold-higher in terms of weight.

Moreover, it has been demonstrated that all the hydrogen solutions are suitable in terms of weight and volume, even if the number voyages (without refueling) are drastically reduced. Finally, different economic scenarios, based on the predicted combined reduction in hydrogen fuel prices and increase in diesel prices, show that the PEMFC powertrain can become comparable with the reference scenario at a hydrogen price of $\$ 4.0 / \mathrm{kg}$. 


\section{Acknowledgment}

This work is supported by e-SHyIPS project, which has received funding from the Fuel Cells and Hydrogen 2 Joint Undertaking (JU) under grant agreement No 101007226. This JU receives support from the European Union's Horizon 2020 research and innovation program, Hydrogen Europe and Hydrogen Europe Research.

\section{References}

1. CE Delft. 45, 2017.

2. Anderson K, Peters G. Science (80- ) 354:182-3, (2016).

3. Bjerkan KY, Seter H Transp Res Part D Transp Environ 72 :243-60, (2019).

4. Rutherford D, Comer B. Int Counc Clean Transp 8 (2018).

5. Bouman EA, Lindstad E, Rialland AI, Strømman AH. Transp Res Part D Transp Environ 52:408-21 (2017).

6. Integration S, Rail H, (2020).

7. Karimi S, Zadeh M, Suul JA. IEEE Electrif Mag 8:47-61 (2020).

8. Ritari A, Huotari J, Halme J, Tammi K. Energy 190: 116359, (2020).

9. Bach H, Bergek A, Bjørgum Ø, Hansen T, Kenzhegaliyeva A, Steen M. Transp Res Part D Transp Environ 87:102492 (2020).

10. Bergek A, Bjørgum Ø, Hansen T, Hanson J, Steen M. 9th Int Sustain Transitions Conf 1-25, (2018).

11. Mao X, Rutherford D, Osipova L, Comer B. (2020).

12. Georgeff AE, Mao X, Rutherford D, Ph D, Osipova L, (2020).

13. C. Dall'Armi, D. Micheli, R. Taccani, Int. J. Hydrogen Energy. 46, (2021).

14. M. Rivarolo, D. Rattazzi, T. Lamberti, L. Magistri, Int. J. Hydrogen Energy. 45, (2020).

15. Choi, C.H.; Yu, S.; Han, I.-S.; Kho, B.-K.; Kang, D.-G.; Lee, H.Y.; Seo, M.-S.; Kong, J.-W.; Kim, G.; Ahn, J.-W.; et al. Int. J. Hydrogen Energy 41, 3591-3599, (2016).

16. Jeong, J.; Seo, S.; You, H.; Chang, D. Int. J. Hydrogen Energy 43, 3809-3821 (2018).

17. Marine Traffic: Global Ship tracking Intelligence.

https://www.marinetraffic.com/en/ais/details/ships/shipid:4975261/mmsi:56303 4100/imo:9797723/vessel:TORM_SOVEREIGN

18. Ro_pax ferry typical layout https://www.google.com/search?q=Typical\%20layout $\% 20$ of $\% 20$ Ro Pax\%20ferry\&tbm=isch\&tbs=rimg:CW2p082Ip7nYap9aaHvBTpL\&hl=en\&sa $=X$ \&ved=0CBsQuIIBahcKEwiYibHPhbrxAhUAAAAAHQAAAAAQFg\&biw=1519 $\underline{\text { \&bih }=754 \# \text { imgrc }=\text { S0WQDLrVMoxSEM\&imgdii }=\mathrm{PjE} 6 \mathrm{X} 1 \mathrm{IHq} 7381 \mathrm{M}}$

19. Dokmar Maritime Publisher, 10, 432, 978-90-71500-40-4, (2003).

20. Ballard, "Fuel Cell Power Module for Heavy Duty Motive Applications," Ballard, Burnaby, (2016).

21. N. De Vries, REPORT THESIS, (2019).

22. Hydrogen-Faber Industry SPA http://www.faber-italy.com/eng-login-scheda-sing.asp

23. Mirai-Toyota Europe https://www.toyotaeurope.com/download/cms/euen/Toyota $\% 20 \mathrm{Mirai} \% 20 \mathrm{FCV}$ Pos ters LR tcm-11-564265.pdf

24. Linde Engineering- Cryogenic standard tanks https://www.linde- 
engineering.com/en/images/P_3_3_e_12_150dpi_tcm19-5774.pdf

25. Raucci C, Smith T, Dodds P. $(201 \overline{7})$.

26. Battelle Memorial Institute, 2017.

27. US DOE. US Drive 2017.

28. Cell F, Office T. U.S. Department of Energy, 2019.

29. Reddi K, Elgowainy A, Rustagi N, Gupta Int J Hydrogen Energy 42:21855-65 (2017)

30. Ahluwalia RK, Peng J, Hua TQ. Compress Cryo-Compressed Hydrog Storage Work (2011).

31. .S Deparment of Energy. Department of Energy. EnergyGov (2017).

32. Cell F, Office T. Adams J. (2020).

33. Rivard E, Trudeau M, Zaghib K. Materials (Basel) (2019).

34. Minnehan, John J Pratt, Joseph W, Sandia Unlimited Release, 1-71, (2017).

35. Wärtsilä $46 \mathrm{~F}$

https://www.wartsila.com/docs/default-source/product-files/engines/ms-

engine/wartsila-o-e-w

46f.pdf?utm source $=$ engines\&utm medium $=$ dieselengines \&utm term $=w 46 \mathrm{f} \& u$ tm content $=$ brochure\&utm campaign $=$ msleadscoring

36. Satyapal S. DOE Hydrog Fuel Cells Progr 1-25, (2020). 